D. Момот

\title{
OPTIMIZATION OF RISKS OF THE INVESTMENT PORTFOLIO OF ART OBJECTS ACCORDING TO THE LEVEL OF FINANCIAL SECURITY OF ART INVESTING IN THE LOCAL ART MARKET
}

The article is devoted to the study of theoretical and methodological principles and development of practical recommendations for optimizing the risks of the investment portfolio of art objects according to the level of financial security of art investing in the local market. The subject of the study is a set of theoretical, methodological and practical aspects for optimizing the risks of the investment portfolio of art objects according to the level of financial security of art investing in the local market. The purpose of the article is to develop theoretical and methodological provisions and substantiate practical recommendations for optimizing the risks of the investment portfolio of art objects according to the level of financial security of art investing in the local market. Objectives: to investigate and systematize the conceptual and categorical apparatus of financial security of art-investment; to develop a methodical approach to assessing the level of investment attractiveness of an art object according to the level of financial security of art investing; to offer analytical and applied support for optimizing the risks of the investment portfolio of art objects according to the level of financial security of art investing in the local art market. During the research the following methods were used: abstract-logical analysis, theoretical generalization, system and statistical analysis, system and statistical analysis, economic-mathematical methods, graphical method. The essence and genesis of the concept of investment as an economic category in the context of the development of the history of economic thought are determined, on the basis of which the specific features of the investment process are generalized, the concept of art-investment is defined. Analytical and applied support for minimizing the risks of the investment portfolio of art objects at the level of financial security of art investment in the local art market and its testing on the example of the author's investment portfolio of art objects of contemporary Ukrainian artists. Conclusions. Analytical and applied support for minimizing the risks of the investment portfolio of art objects by the level of financial security of art investing in the local art market was developed. It allows to determine the investment potential of the art object by the components of financial security of art investment by the parameters of the internal environment based on the assessment of the multiplier to assess the investment attractiveness of art objects; to establish the priority of investing in art object as part of the investment portfolio; to position each art object on the matrix taking into account the emotional effect of ownership of the art object for the investor.

Keywords: investment portfolio of art objects; art investing; financial security of art investing; risks of art investing; investment attractiveness of art objects; multiplier of investment attractiveness of an art object; investment potential of an art object.

\section{Introduction}

Investment belongs to the economic categories that determine the process of consistent transformation of initially accumulated resources into a product of the investment sphere in order to increase profits in the long run and/or achieve another effect. Investing in art objects is an alternative type of investment, which is characterized by specific features and requires the development of modern theoretical and methodological support and practical tools for decision-making on the implementation of art investing, taking into account proposals formulated in various economic theories and conjuncture art market [1].

Therefore, the search for ways to protect the interests of art investors from external and internal threats and minimize the risks of investing in art objects is a relevant and timely area of research.

\section{Analysis of recent research and publications}

The work of many foreign researchers is devoted to the study of the problem of investment, namely: T. Veblen, J. Dunning, O. Domar, D. Keynes, R. Coase, J. Linter, G. Markovic, P. Masse, W. Mitchell, J. Mossin, M. Porter, P. Samuelson, I. Fischer, E. Hansen, R. Harrod, D. Hicks, W. Sharpe and many others.

Among domestic economists who have studied this problem, it is worth noting the work of researchers such as: V.D. Bazylevych, L.Ya. Korniychuk, T.V. Mayorova,
A.A. Peresada, A.V. Cherep and others.

However, despite the significant developments of scientists, a relevant and necessary step is the further development of theoretical and methodological provisions for optimizing the risks of the investment portfolio of art objects according to the level of financial security of art investing in the local art market. Thus, the theoretical and methodological and applied value of solving the outlined problems determined the relevance of the chosen topic, determined the purpose, objectives and direction of the study.

\section{Goals and objectives of the study}

The purpose of the article is to develop theoretical and methodological provisions for optimizing the risks of the investment portfolio of art objects according to the level of financial security of art investing in the local art market.

\section{Materials and methods of research}

The theoretical and methodological basis of the study was the scientific works of leading domestic scientists and foreign economists. In the course of the research such methods were used as: abstract-logical analysis, dialectical, theoretical generalization, system and statistical analysis, system and statistical analysis, economic-mathematical methods, graphic method. 


\section{Research results and their discussion}

Review and generalization of literature sources allows us to say that historically in foreign literature, the category of investment is interpreted as goods and values that are invested in business activities to obtain future income.

As historical and economic sources show, the prototype of modern investment was "money", "savings", "accumulation", "capital".

Since the era of mercantilism, investment has been seen as an initial advance, a "cumulative value". Considering money as a commodity, Jean Colbert $(1619-1683)$ considered the first objective prerequisite for industrial development by rich people to invest the accumulated money in production.

François Quesnay $(1694-1774)$ formulates the concept of investment as initial advances or capital investments. F. Quesnay argued that capital is not money, but what is bought for money, ie the means of production used in agriculture [2]. Moreover, money, according to F. Quesnay - is a barren wealth, so he was opposed to the accumulation of money, turning them into treasure. Developing the theory of F. Quesnay, who considered capital in kind, Jacques Turgot $(1727-1781)$ defines it as "accumulated value".

The founder of the classical school of political economy Adam Smith (1723 - 1790) in his work "Studies on the nature and causes of wealth of peoples" concluded that the intensification of investment processes associated with the accumulation of capital, which, in turn, is a consequence of savings, in based on net income. Real wealth is not proportional to gross but to net income. The greatest amount of wealth can be achieved by giving everyone full economic freedom [3]. The representative of the classical school of political economy David Ricardo $(1772-1823)$ gives his own interpretation of the problem of investing capital. He notes that the only source of growth of the nation's wealth is the accumulation in conditions of free competition. He supported proposals to liberalize the economy and freedom of trade and denied the possibility of forced savings. The classical school of political economy significantly influenced the further development of investment theories and doctrines in the works of economists of the new wave of the first half of the XIX century: Thomas Malthus (1766 - 1834), James Lauderdale (1759-1839), James Mill (177 - 1836) and others. Scholars consider means to stabilize investment flows through government regulation, in particular through government monetary policy.

During the completion of the industrial revolution and the aggravation of socio-economic contradictions in the 40th of the XIX century economic ideas of Marxism begin to take shape. Thus, Karl Marx in his "Capital" distinguishes the monetary form of capital. The specific nature of this form of capital, according to K. Marx, is determined by the fact that money (because it can be converted into a self-increasing value) has an additional consumer value, which is their ability to "function as capital and in this guise to produce average profit on average". K. Marx argued that there is no problem of stimulating investment, because under capitalism, all savings are invested in order to gain a competitive advantage in the pursuit of super profits [4].

In the second half of the XIX century and at the beginning of the XX century there is a transformation of the classical investment concept into new neoclassical theories. Within the tradition of the Austrian scientific school, human activity in the market is studied as a process of coordinating successive changes that occur over time, whose participants act according to their own knowledge, beliefs, expectations, produce new information, find new opportunities, realize their creative potential. Representatives of the Austrian scientific school of marginal utility interpret investment as the exchange of satisfaction of today's needs for their satisfaction in the future with the help of invested goods. Thus, Carl Menger $(1840-1921)$ believes that value is only subjective and exists in human consciousness. Labor expended on the production of a good cannot act as a measure of the value of the good. Value depends only on people's subjective evaluation, and they, in turn, always value relatively rare goods the most. For example, a painting by da Vinci and a painting by a modern novice artist will have completely different values (even if the same amount of work is spent on the creation of these paintings). O. Bem-Bawerk (1851-1919) argued that savings by limiting consumption are necessary for economic growth. He sees public and private funds as a source of investment for entrepreneurship, new technologies and capital formation.

In the 20th of the twentieth century in the United States, the idea of stabilizing the economy through the regulation of the investment cycle through a prudent monetary policy is developing, the leader of the group of economists who support this direction was Irving Fisher (1867-1946). In his works, he describes for the first time a pattern called the "Fisher effect", according to which the projected increase in inflation leads to a proportional increase in interest rates and, conversely, lowering the projected inflation rate leads to lower interest rates. Subsequently, the "Fisher's rule" was called the shrinking of the investment potential of society and the slowdown in economic growth due to the expanding monetary policy of the state and inflation [5].

Thus, on the basis of classical and neoclassical theories, it was proved that investment processes are not subject to self-regulation, but require coordination by the state, which contributed to the introduction of the doctrine of state regulation of the economy.

According to the theory of John Maynard Keynes (1883-1946), investment is considered as a current increase in the value of capital assets as a result of production activities of this period, this is the part of income for this period that was not used for consumption [6]. According to the new theoretical conclusions obtained by J.M.Keynes: there is no automatic mechanism for balancing savings and investment; the excess of savings over investment leads to a decrease in business activity; the condition of macroeconomic equilibrium is their equality. Thus, J.M.Keynes singles out the dual essence of investment: on the one hand, investment is the amount of accumulated income for the purpose of accumulation, the 
amount of investment resources. On the other hand - it is an investment (cost), which determines the increase in capital as realized investment supply and demand. J.M. Keynes first justified the need to stimulate the investment process by stimulating effective consumer demand through monetary and fiscal policy. A significant achievement of J.M. Keynes is the development of an investment multiplier mechanism (the ratio of income to investment), which allows him to formulate a rule that any new increase in investment automatically provides an increase in total income, in which the share of savings grows faster than the share, which is consumed, and, consequently, provides the basis for future investment. As part of the development of microeconomic investment analysis, J.M. Keynes proved that the investment behavior of the firm is determined by such factors as the level of accumulation, the level of investment income and interest rates in the credit market.

In the postwar period of development of market economies of developed countries, followers of J. Keynes (E. Hansen, R. Harrod, J. Hicks, O. Domar, P. Samuelson) created a neo-Keynesian theory of economic dynamics and growth, the main content of which is the problem of economic equilibrium by state regulation of investment activity using methods of state influence such as the state budget as a "built-in stabilizer"; stimulated investment that provides economic growth in a guaranteed, natural and actual pace; state regulation of interest rates.

The next stage in the development of theoretical thought in the field of investment was the development of ideas of institutionalism through the study of investment processes through the prism of social and political problems and improving research tools and terminology institutions, transaction costs, limited rationality, opportunistic behavior, contracts, specific assets, and institutional changes. Representatives of the institutional direction, in particular A. Spithof, T. Veblen, J. Commons, W. Mitchell, R. Croes, focused on social institutions. Ronald Coase, a professor at the University of Chicago and winner of the Nobel Prize in Economics (1991), argued that transactions involve the costs of using a market mechanism that he called transactional, leading to redistribution of property rights and affecting the structure and efficiency of production. Proponents of this scientific school to the main institutions of a favorable investment environment, along with economic, included institutional (institutional structure of society; legal framework; development of ideology, etc.) and social (state and needs of social development).

The generalization of the achievements of the neoclassical, Keynesian, institutional directions of investment research is presented in the modern synthesis of investment theories of the famous Nobel laureates G. Markovic, M. Miller, F. Modigliani, W. Sharp, D. Tobin, R. Solow.

The founder of modern portfolio theory (evaluation of the efficiency of the investment portfolio) was the winner of the Nobel Prize (1990) for his work on the theory of financial economics G. Markowitz. $\mathrm{He}$ developed a new approach to the study of the effects of investment risk on the basis of his own theory of asset allocation in the investment portfolio in conditions of uncertainty [7].

It is generally accepted that the main contribution to the theory of capital structure and prices of funding sources was made by F. Modigliani (1918-2003) and M. Miller (1923-2000), who argue that in the absence of taxes the value of the company's capital does not depend on its structure, the company's decision on new investments does not depend on the dividend policy it pursues, the total market value of the company does not depend on the amount of debt in the capital structure [8].

Laureate of the Nobel Prize (1990) for his work on the theory of financial economics, W. Sharp develops the theory of the ratio of risk and return on investment in securities. First, W. Sharp divided the overall risk of investing in securities into two parts: systematic risk, which is associated with the system of economic and financial relations (non-diversified risk) and nonsystematic risk (diversified, or portfolio). Second, W. Sharp proposed the Capital Asset Pricing Model (CAPM), which allows a corporation to determine the cost of capital needed to do business. Third, W. Sharp established the procedure for forming the investment portfolio of securities in stages: the choice of investment policy, analysis of the securities market, the formation of the securities portfolio, focusing on the security aspect of investing [9].

In their research, W. Sharp, G.J. Alexander, J.W. Bailey in a broad sense consider investing as "parting with money today to get their increased amount in the future."Scientists identify two factors associated with the investment process - time and risk [10]. The investment process is directly related to the time factor. There is always a time lag between capital investment and investment income, which can be characterized by different intervals. When making an investment, the investor always takes the risk associated with a possible reduction or non-receipt of the expected return, as well as a possible loss (partial or full) of the amount of invested capital. The authors proved that the level of investment risk is directly dependent on the level of their expected return.

Modern investment theories are developing in the direction of studying the processes of capital export abroad in the form of foreign direct investment (FDI) and the motivation of investors, the development of the theory of transnational corporations. Significant contributions to the development of this area of research have been made by such scientists as S. Hymer, J. Dunning, T. Horst, R. Vernon, S. Menardi, M. Porter, M. Casson, and others.

The most common conceptual approach to explaining the process of foreign direct investment was the eclectic paradigm of international production of J. Dunning (1976), based on three objective components that influence the company's choice of different models of entry into specific markets: the benefits of ownership (O - ownership advantages), location advantages ( $\mathrm{L}$ - location advantages) and internalization advantages (I - internalization advantages). J. Dunning's Concept of Investment Development Path (IDP) was put forward in 1979 , according to which the import and export of capital 
of a certain country are directly dependent on the level of its economic development in comparison with other countries [11].

M. Porter's large-scale study on the impact of competitive advantage contributes to a better understanding of transnational activities of companies, taking into account four factors: factor 1: corporate strategy, structure and competition: management and leadership, company goals, new business and entrepreneurship, venture capital, etc.; factor 2: the state of factors, including human, physical, knowledge, capital, infrastructure; factor 3: components of demand, such as the volume of demand in the country, its growth rate, consumer segmentation, consumer characteristics; factor 4: the existence of related and supporting industries [12].

The eclectic paradigm of J. Dunning was further developed in the works of J. Marcusen, W. Isier, and E. Helpman, who proposed a number of approaches united by the concept of "knowledge - capital". They explained the key advantages of OLI - the paradigm from the standpoint of assessing knowledge as capital, covering human capital, patents, trademarks, reputation and other types of knowledge.

Leading representative of the Chicago School of Economics, winner of the Alfred Nobel Prize in Economics for achievements in research in the field of consumption analysis, the history of money circulation and the development of monetary theory, as well as for practical demonstration of the complexity of economic stabilization policy (1976) Milton Friedman (1912-2006), like other neoliberals, recognizes that a market economy has great internal potential for self-balancing and selfregulation. He proposes to limit intervention in the economy to the macroeconomic sphere, in particular control over money circulation [13].

Modern foreign scholars Z. Bodie, A. Kane and A. J. Marcus consider investment as the cost of money and other resources in the present period to obtain benefits in the future [14]. A similar view is shared by the French economist P. Masse, who sees investing as an act of future satisfaction from current investment benefits [15].

Thus, Western scientific thought about the investment process was formed in the evolutionary development of theories of finance. Investments are considered as a set of all types of resources (goods, property and intellectual values) invested in objects of entrepreneurial and other activities, as a result of which profit (income) is created or other effect (social, ecological and other types of effect) is achieved in the future.

In Ukraine, the development of scientific approaches to investing begins in the early 90th. Based on world experience, Ukrainian scientists are developing a theoretical and methodological basis for investment decisions.

Summing up the historical discourse on the formation of the theory of investment activity, we note that the results of the study can identify such specific features of the investment process.
First, in general, investing is a process of unity of investment processes with the prospect of profit or other effect.

Second, investing is a long process during which the following transformations take place: investment resources (goods, values) $\rightarrow$ investments (costs) $\rightarrow$ increase in capital value $\rightarrow$ profit (effect). In the first stage, investment actually takes place - the process of transforming investments into objects of investment activity. In the second stage, there is a modification of investment in capital growth. At the final stage, the ultimate goal of investing is realized - to make a profit or other effect.

Third, it is important to realize the fact that investment activity, as a way to combine investment needs with investment opportunities, covers not only the investment cycle, but also the further management of property created in the investment process. Therefore, it is expedient to distinguish two stages of the investment cycle: the creation of capital value and its functioning (operation).

Fourth, investment activity is carried out in the investment sphere, which is a system of economic relations concerning the movement (realization) of investments. It is in the investment sphere that the proportions between accumulation and investment, investment and capital value growth, investment of investment resources and return on investment are formed.

Fifth, the development of the investment sphere is closely related to the development of the investment market, which synthesizes the supply of investment (capital) by potential investors and the demand for investment by potential participants in investment activities. Thus purchase and sale of the capital in the market of investments take place proceeding from prospects of reception of the future profits which exceed their current level.

Sixth, investing is based on the coincidence of interests of participants in the investment process, which is associated with one of the main features of investing the target.

Seventh, investment is the bearer of property rights and dispositions. Capital invested as an accumulated investment resource can act as a carrier of all forms of ownership - individual private, collective private, municipal, national, and so on.

Eighth, investments are characterized by liquidity, ie in the event of adverse conditions of the internal or external environment, investments can be realized, which will ensure the release of invested capital. In this case, the main parameter of liquidity assessment is the period of time during which the invested capital can be converted into cash without losing its real market value.

This understanding of the economic essence of investment makes it possible to determine the economic essence of the category of art investment. Art-investing is a form of placing capital in art-objects of investment quality in case a potential investor has accumulated (free) capital and is an alternative type of investment activity carried out in order to obtain a monetary return with minimal risk of losing investment and/or achieving other 
effect in the future; hedging potential capital loss risks; investing in cultural development (aestheticization) or achieving an emotional effect. The main purpose of art investing is to invest capital in the most investmentattractive art objects in order to obtain maximum profit or achieve another beneficial effect for the investor. At the same time, it is important to ensure the financial security of art investing, which requires the development of modern tools to minimize investment risks.

Optimizing the portfolio of art objects according to the level of financial security of art investing is an important component of the process of managing the financial security of art investing, which should be carried out using scientifically sound tools at the stage of decision-making on art investing. As a result indicator for assessing the priority of investing in an art object in the investment portfolio, it is proposed to determine the multiplier of investment attractiveness of the art object by the formula (1):

$$
I A i=\frac{S i}{A R T f s i^{\text {int }}} \rightarrow \min ,
$$

where $I A i$ is a multiplier of the investment attractiveness of the art object; $S_{i}$ - price of the i-th art object; ARTfsi ${ }^{\text {int }}$ financial security indicator of the $i$-th art object, calculated by the components of the internal environment.

The multiplier of the investment attractiveness of the art object allows you to assess the effect of minimizing the risks of investing in the art object by the components of the internal environment. The proposed indicator allows you to calculate how many monetary units of the value of the art object per one rating point of the indicator of financial security of investing in the art object, calculated by the components of the internal environment. The lower this figure, the lower the level of risk of investing in an art object relative to the level of financial security of art investing. Of course, the stimulating effect of the multiplier of the investment attractiveness of an art object depends on many factors. Thus, if the financial security of the art object increases by the components of the internal environment, the multiplier of the investment attractiveness of the art object decreases, which makes it appropriate to implement measures to minimize the risks of art investing, taking into account the effects of multiplier links.

Considering the proposed multiplier of the investment attractiveness of the art object as a result, it was decomposed according to the key indicators of financial security management of art investment for the local art market (fig. 1).

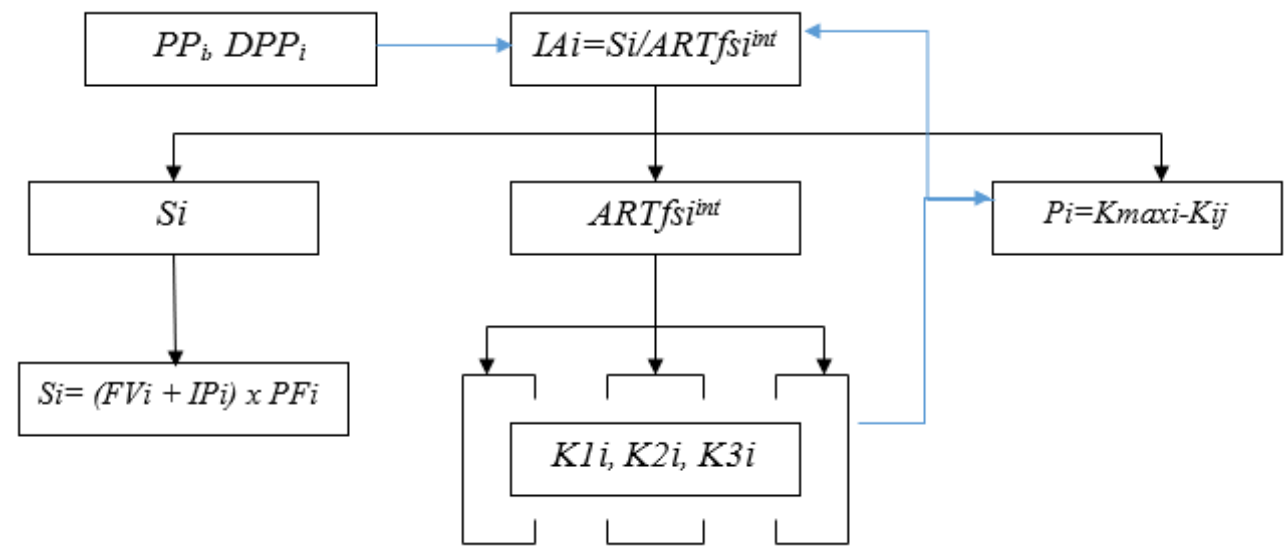

Fig. 1. Model of parameters for assessing the investment attractiveness of the portfolio of art objects by the level of financial security of art investment for the local art market (made by the author)

where $P P_{i}, D P P_{i}$ is a payback period of investment in an art object; $I A i$ is a criterion of investment attractiveness of an art object; $S_{i}$ - estimated price of the $i$-th art object or resale value (prospective value); FVi (Fair Value) $i$ - fair price of the $i$-th art object; IP $i$ (Irrational Premium) premium for irrationality (or the price of perception); $P F i$ (Provenance Multiplier) - provenance multiplier; ARTfsi $i^{\text {int }}$ - financial security indicator of the $i$-th art object, calculated by the components of the internal environment $(K 1, K 2, K 3) ; K 1$ - component of investment attractiveness of the $i$-th art object; $K 2$ - component of the author's activity for the $i$-th art object; $K 3$ - component of the valuation of the $i$-th art object.

The investment attractiveness potential of the art object is proposed to be defined as the possibility of increasing the financial security parameters of the art object, calculated by the components of the internal environment, by comparing the estimates of the art object with the maximum possible level of the parameter.

It is proposed to calculate the potential to increase the level of financial security of the art object in terms of each component of financial security of the internal environment by the formula (2):

$$
\stackrel{n}{P}=\left(\max K_{i}-K_{i j}\right), j=1,2, \ldots, m,
$$

where $\stackrel{n}{P}$ - is a potential of investment attractiveness by the $i$-th parameter for the $j$-th art object; $\max K i-$ the maximum value of the $i$-th parameter; $K_{i j}$ - evaluation of the $i$-th parameter for the $j$-th art object; $n$ - the number of parameters of a comprehensive indicator of financial 
security of art investment; $m$ - the number of art objects in the investor's portfolio.

The proposed model of parameters allows to assess the investment risks of the portfolio of art objects and to ensure their minimization by using the identified potential to increase the financial security of the art object in the local art market.

Based on the results of calculations, the target parameters for each art object of the investment portfolio relative to the selected parameter of financial security of art investment are set, which are perspective-oriented and allow to determine the trajectory of investment portfolio optimization according to selected parameters of financial security of art investment.

Approbation of the developed analytical and applied support to minimize the risks of the investment portfolio of art objects according to the level of financial security of art investing in the local art market using the proposed model is carried out on the example of the investment portfolio of art objects of contemporary Ukrainian artists (table 1).

Table 1. Investment portfolio of art objects of contemporary Ukrainian artists

\begin{tabular}{|l|l|l|l|c|}
\hline \multicolumn{2}{|c|}{ Author } & Name of the art object & Description of the art object & $\begin{array}{c}\text { Price of the art object, } \\
\text { USD }\end{array}$ \\
\hline Winnie Reunov & AO1 & $\begin{array}{l}\text { Oxford University } \\
\text { Press }\end{array}$ & 2009, canvas, oil, $150 \times 110 \mathrm{~cm}$ & 9000 \\
\hline Alexander Voronin & AO2 & Innocence & 2013, etching, paper, $60 \times 96 \mathrm{~cm}$ & 600 \\
\hline $\begin{array}{l}\text { Igor Kanivets and } \\
\text { Margarita Sherstyuk }\end{array}$ & AO3 & Personal space & 2014, oil on canvas, $120 \times 180 \mathrm{~cm}$ & 4000 \\
\hline Andriy Bludov & AO4 & Delhi Museum & $\begin{array}{l}2016, \text { canvas, oil, silk-screen paint, } \\
100 \times 80 \mathrm{~cm}\end{array}$ & 4000 \\
\hline Elmira Shemsidinova & AO5 & Prickly pear & 2017, canvas, oil paint, $120 \times 120 \mathrm{~cm}$ & 2000 \\
\hline Maxim Mazur & AO6 & Figure 9 & 2019, mixed media, $75 \times 100 \mathrm{~cm}$ & 700 \\
\hline Julia Mokhovikova & AO7 & Son of the sun & $120 \times 1902020$ oil on canvas & 5000 \\
\hline Alexander Roitburd & AO8 & Two & $140 \times 120$, oil on canvas & 12000 \\
\hline Yuri Siviryn & AO9 & no title & $200 \times 150 \mathrm{~cm}$ canvas acrylic 2020 & 5000 \\
\hline
\end{tabular}

For each art object, matrices for assessing the level of financial security of art investment according to the selected parameters of the internal environment are compiled (table 3 ).

The final matrix for assessing the level of financial security of art investment by selected parameters of the internal environment for all art objects of the investment portfolio of art objects selected for study by contemporary Ukrainian artists with the multiplier of investment attractiveness of the art object is presented in table 2.

Table 2. The final matrix for assessing the level of financial security of art investment according to the selected parameters of the internal environment of the investment portfolio of art objects of contemporary Ukrainian artists made by the author

\begin{tabular}{|l|c|c|c|c|c|}
\hline AO & K1 $\mathbf{m a x}=\mathbf{1 6}$ & $\begin{array}{c}\mathbf{K 2} \\
\mathbf{m a x}=\mathbf{1 8}\end{array}$ & $\mathbf{K 3} \mathbf{m a x}=\mathbf{1 4}$ & $\begin{array}{c}\text { ARTfs } \\
\mathbf{m a x}=\mathbf{4 8}\end{array}$ & IA \\
\hline AO1 & 7 & 6 & 6 & 19 & 473,68 \\
\hline AO2 & 7 & 8 & 4 & 19 & 31,58 \\
\hline AO3 & 9 & 8 & 6 & 23 & 173,91 \\
\hline AO4 & 9 & 10 & 7 & 26 & 153,85 \\
\hline AO5 & 9 & 10 & 4 & 23 & 86,96 \\
\hline AO6 & 7 & 5 & 3 & 15 & 46,67 \\
\hline AO7 & 8 & 10 & 5 & 23 & 217,39 \\
\hline AO8 & 11 & 14 & 8 & 33 & 363,64 \\
\hline AO9 & 10 & 14 & 6 & 30 & 166,67 \\
\hline
\end{tabular}


Graphically, the profile of financial security of art investment according to the selected parameters of the internal environment of the investment portfolio of art objects of contemporary Ukrainian artists is presented in fig. 2.

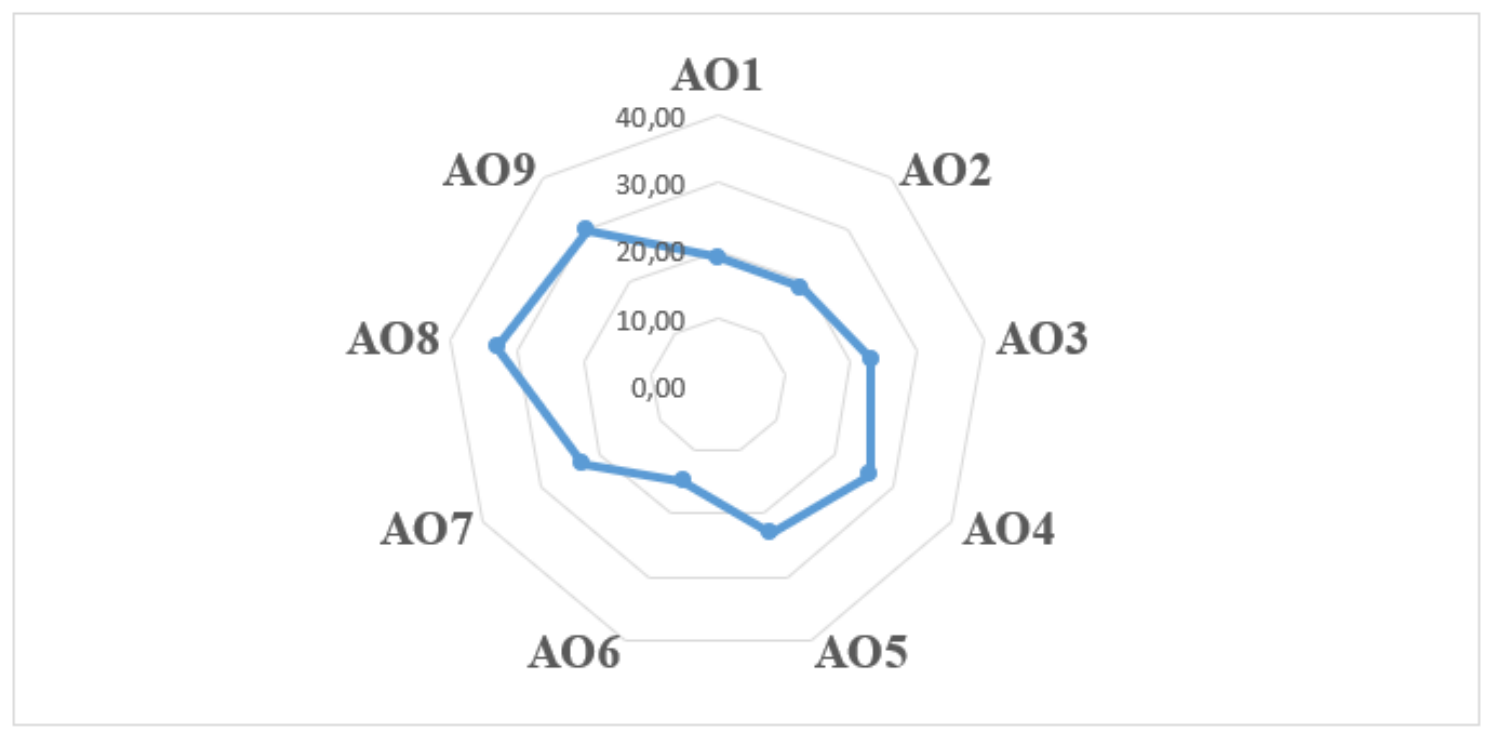

Fig. 2. Profile of the assessment of financial security of art-investment according to the selected parameters of the internal environment of the investment portfolio of art-objects of contemporary Ukrainian artists

The final parametric matrix of assessment of the level of financial security of art-investment according to the selected parameters of the internal environment of the investment portfolio of art-objects of contemporary Ukrainian artists is presented in table 3.

The obtained data allow to establish the priority of investing in art objects of the presented investment portfolio according to the parameters of financial security of the internal environment in the following sequence: $\mathrm{AO} 2, \mathrm{AO} 6, \mathrm{AO} 5, \mathrm{AO} 4, \mathrm{AO} 9, \mathrm{AO} 3, \mathrm{AO} 7, \mathrm{AO} 8, \mathrm{AO} 1$. Graphically, the diagram of the multiplier of investment attractiveness of the investment portfolio of art objects of contemporary Ukrainian artists is presented in fig. 3.

The results show that the smaller is the value of the obtained investment attractiveness multiplier, the less risky is the investment in the art object.

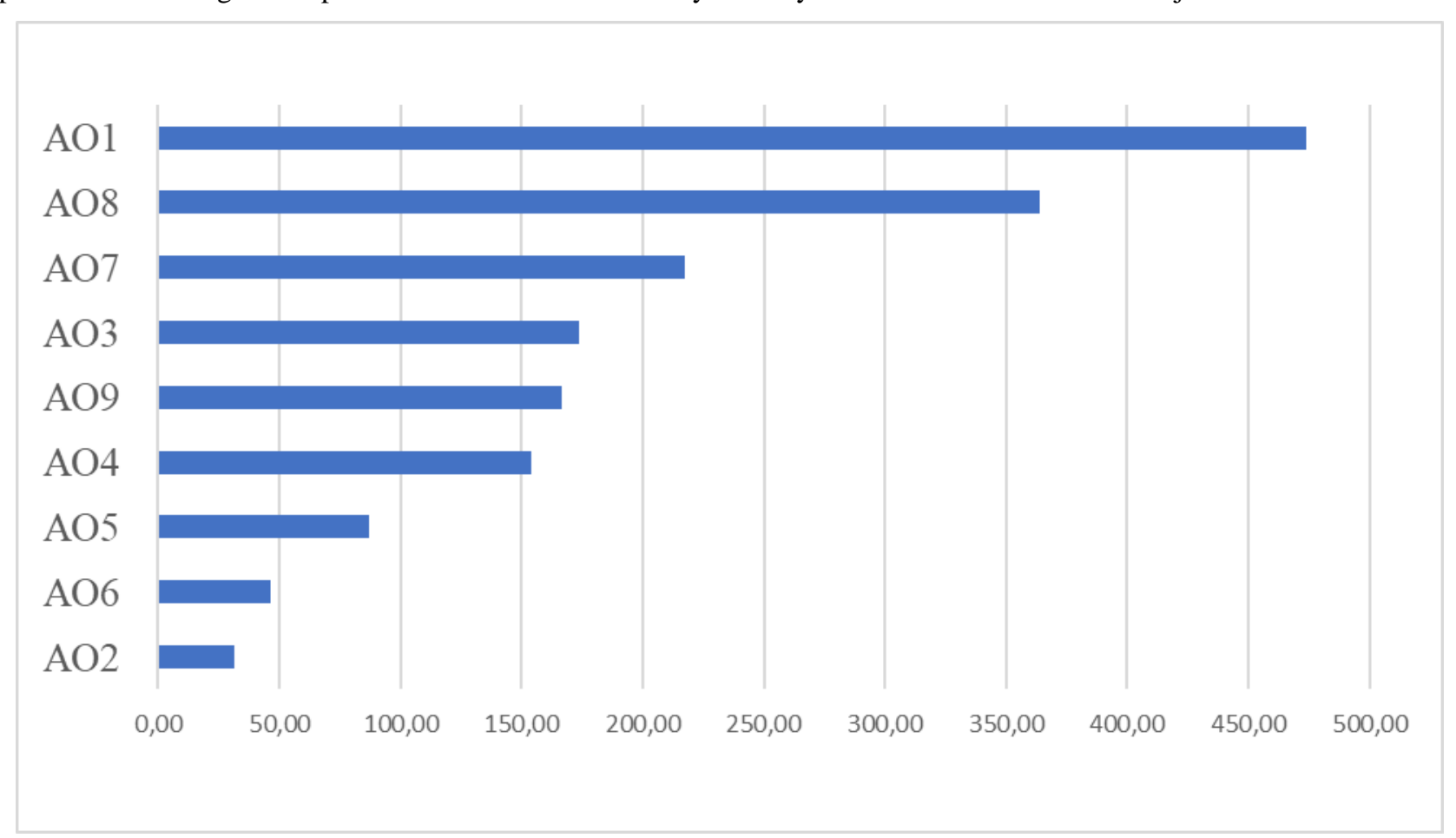

Fig. 3. The multiplier of investment attractiveness of art objects of the investment portfolio of contemporary Ukrainian artists 


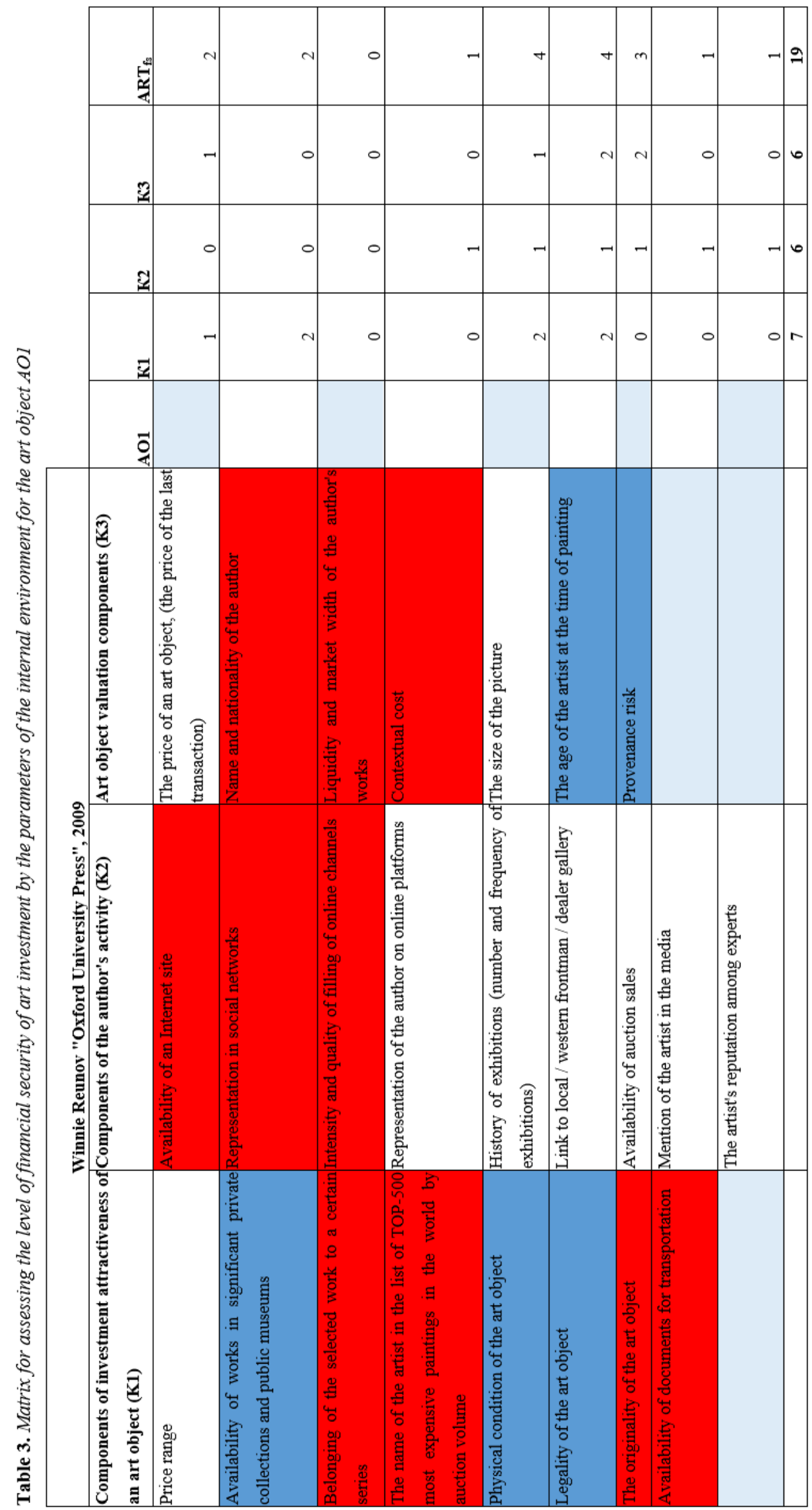


The proposed methodological approach to assessing the level of financial security of art investment for art objects of the investment portfolio allows to develop a trajectory of minimizing the risks of investing in an art object according to the established components of financial security of the internal environment of art investing. To do this, the matrix of investment potential of the art object is built according to the components of financial security of art investment according to the parameters of the internal environment (table 4).

Table 4. Matrix of investment potential of an art object by components of financial security of art-investment by parameters of the internal environment (made by the author)

\begin{tabular}{|c|c|c|c|c|}
\hline AO & K1 $\mathbf{m a x}=\mathbf{1 6}$ & $\mathbf{K 2} \mathbf{m a x}=\mathbf{1 8}$ & $\mathbf{K 3} \mathbf{m a x}=\mathbf{1 4}$ & ART \\
\hline AO1 & 9 & 12 & 8 & 29 \\
\hline AO2 & 9 & 10 & 10 & 29 \\
\hline AO3 & 7 & 10 & 8 & 25 \\
\hline AO4 & 7 & 8 & 7 & 22 \\
\hline AO5 & 7 & 8 & 10 & 25 \\
\hline AO6 & 9 & 13 & 9 & 33 \\
\hline AO7 & 8 & 8 & 6 & 25 \\
\hline AO8 & 5 & 4 & 8 & 11 \\
\hline AO9 & 6 & 4 & & 18 \\
\hline
\end{tabular}

However, promising for the final decision on investing in an art object is the positioning of each art object on the matrix, taking into account the emotional effect of owning an art object for the investor.

Emotional effects include, but are not limited to, aesthetic pleasure and other effects of prestige and complementarity. Emotionally reacting to the objects of the surrounding reality is a natural property of man.
However, to assess the importance of aesthetic pleasure is quite difficult, because beauty and its role in the life of each person are individual. In the framework of this study, approaches to the assessment of the emotional effect are systematized and the art objects of the investment portfolio are positioned according to the level of the multiplier of investment attractiveness and the emotional effect of owning an art object on the matrix (table 5).

Table 5. Matrix of positioning of art objects of investment portfolio on the level of multiplier of investment attractiveness and emotional effect from possession of art object (made by the author)

\begin{tabular}{|c|c|c|c|}
\hline & $\begin{array}{c}\text { AO } \\
\text { With the greatest emotional } \\
\text { effect }\end{array}$ & $\begin{array}{c}\text { AO } \\
\text { With an average emotional } \\
\text { effect }\end{array}$ & With low emotional effect \\
\hline $\begin{array}{c}\text { AO with high investment } \\
\text { attractiveness } \\
(199-1)\end{array}$ & AO2, AO6, AO5 & AO4, AO9 & AO3 \\
\hline $\begin{array}{c}\text { AO with average investment } \\
\text { attractiveness } \\
(349-200)\end{array}$ & AO7 & \\
\hline $\begin{array}{c}\text { IA } \\
\text { AO with low investment } \\
\text { attractiveness } \\
(500-350)\end{array}$ & AO8 & \\
\hline
\end{tabular}

Therefore, based on the results of the positioning, a matrix is obtained, which allows to select the optimal possible solutions for art investing, taking into account the level of financial security and investment potential from many options for the development of the situation.

\section{Conclusions}

According to the results of the study, the essence and genesis of the concept of investment as an economic category in the context of the history of economic thought (for 4 centuries) in the works of economists and identified their main achievements that formed the basis for the formation of theoretical and methodological principles of financial security management .of art-investment and optimization of risks of the investment portfolio of art objects according to the level of financial security of artinvesting in the local market.

Art-investing is defined as a form of capital placement in art objects of investment quality in case a potential investor has accumulated (free) capital and is an alternative type of investment activity carried out in order to obtain monetary income with minimal risk of investment loss and/or achievement another effect in the future; hedging potential capital loss risks; investing in cultural development (aestheticization) or achieving an 
emotional effect. The main purpose of art investing is to invest capital in the most investment-attractive art objects in order to obtain maximum profit or achieve another beneficial effect for the investor.

To minimize the risks of art investment, analytical and applied software for minimizing the risks of the investment portfolio of art objects according to the level of financial security of art investing in the local art market, based on calculating the investment attractiveness multiplier of the art object as a result indicator priority of investing in an art object as part of the investment portfolio. A model of decomposition of the multiplier of investment attractiveness of an art object according to key indicators of financial security management of artinvestment for the local art market has been developed.
The approbation of the developed analytical and applied support was carried out on the example of the art portfolio of art objects of contemporary Ukrainian artists formed by the author.

The calculation results in the trajectory of minimizing the risks of investing in an art object according to the established components of the financial security of the internal environment of art investing by building a matrix of investment potential of the art object for the financial security components of art investing according to the internal environment.

It is proved that in order to make a final decision on investing in an art object, it is advisable to position each art object on the matrix, taking into account the emotional effect of owning an art object for the investor.

\section{References}

1. Momot T., Momot, D. (2018), "Art-industry market infrastructure: the analysis of modern structure and functions", Innovative Technologies and Scientific Solutions for Industries, No. 2 (4), P. 34-44. DOI: https://doi.org/10.30837/2522-9818.2018.4.034

2. Kene, F. (1960), Farmers: Selected Economic Studies [Fermery: Izbrannyye ekonomicheskiye pronzvedennya], Moscow, From-in social-zkon. lit., $567 \mathrm{p}$

3. Smith, A. (2007), Research on the nature and causes of the wealth of peoples [Issledovaniye o prirode i prichinakh bogatstva narodov], Moscow, Eksmo, Series: Anthology of Economic Thought, 960 p.

4. Marks, K. (1978), Capital. Criticism of Political Economy [Kapital. Kritika politicheskoy ekonomii], Vol. I : Capital production process, Moscow, Politizdat, 891p.

5. Fisher, I. (1930), "The Theory of Interest" [Electronic resource], New York, available at : http//www.ekonlib.org/library/YPDBooks/Fisher/fshTol.html

6. Keynes, J. M. (1973), "General Theory of Employment, Interestand Money", Collected Writings of John Maynard Keynes, Vol. VII, London, Macmillan.

7. Markowitz, H. M. (1956), Portfolio Selection. Efficient Diversification of Investments, NewYork, Wiley.

8. Modigliani, F. M. Miller (1958), The Cost of Capital, Corporation Finance and Theory of Investment, American Economic Review, $48 \mathrm{p}$

9. Sharpe, W. (1985), Investment, NewYork, PrenticeHall.

10. Sharpe W., Alexander, G., Bailey, J. (1999), Investments [Investitsii] : transl. from English, Moscow, INFRA-M, 1028 p.

11. Dunning, J. (1990), "The eclectic paradigm as an envelope for economic and business theories of MNE activity", International Business Review, Vol. 9, P. 163-190.

12. Porter, M. E. (1990), The Competitive Advantage of Nations, N. Y., The Free Press, A Division of Macmillan, Inc., 895 p.

13. Friedman, M. (2006), Capitalism and Freedom [Kapitalizm i svoboda] : Per. from English, Moscow, New publishing house, $240 \mathrm{p}$.

14. Bodie, Z., Kane, A., Markus, A. (2008), Principles of Investment [Printsipy investitsiy], Moscow, Williams, 984 p.

15. Masse, P. (1971), Criteria and Methods for Optimal Investment Determination [Kriterii i metody optimal'nogo opredileniya kapitalovlozheniya], Moscow, 503 p.

Received 18.08.2020

\section{Відомості про авторів / Сведения об авторах / About the Authors}

Момот Дарина Тарасівна - Харківський національний університет міського господарства імені О. М. Бекетова, аспірант кафедри менеджменту i публічного адміністрування, Харків, Україна; email: momotdaryna@gmail.com; ORCID: 0000-0002-6026-541X.

Момот Дарина Тарасовна - Харьковский национальный университет городского хозяйства имени А. Н. Бекетова, аспирант кафедры менеджмента и публичного администрирования, Харьков, Украина.

Momot Daryna - O. M. Beketov Kharkiv National University of Urban Economy, Ph.D student of the Department of Management and Public Administration, Kharkiv, Ukraine.

\section{ОПТИМІЗАЦІЯ РИЗИКІВ ІНВЕСТИЦІЙНОГО ПОРТФЕЛЮ АРТ-ОБ’СКТІВ ЗА РІВНЕМ ФІНАНСОВОЇ БЕЗПЕКИ АРТ-ІНВЕСТУВАННЯ НА ЛОКАЛЬНОМУ АРТ-РИНКУ}

Стаття присвячена дослідженню теоретико-методичних засад і розробці практичних рекомендацій щодо оптимізації ризиків інвестиційного портфелю арт-об'єктів за рівнем фінансової безпеки арт-інвестування на локальному ринку. Предметом дослідження $\epsilon$ сукупність теоретичних, методичних і практичних аспектів щодо оптимізації ризиків інвестиційного портфелю арт-об'єктів за рівнем фінансової безпеки арт-інвестування на локальному ринку. Метою статті $\epsilon$ розробка теоретико-методичних положень та обгрунтування практичних рекомендацій щодо оптимізації ризиків інвестиційного портфелю арт-об'єктів за рівнем фінансової безпеки арт-інвестування на локальному ринку. Завдання роботи: дослідити та 
систематизувати понятійно-категоріальний апарат забезпечення фінансової безпеки арт-інвестування; розробити методичний підхід до оцінки рівня інвестиційної привабливості арт-об'єкта за рівнем фінансової безпеки арт-інвестування; запропонувати аналітико-прикладне забезпечення оптимізації ризиків інвестиційного портфелю арт-об'єктів за рівнем фінансової безпеки арт-інвестування на локальному арт-ринку. У ході дослідження використано методи: абстрактнологічний аналіз, теоретичного узагальнення, системного та статистичного аналізу, системний та статистичний аналіз, економіко-математичні методи, графічний метод. В роботі визначено сутність та генезис поняття інвестицій як економічної категорії в контексті розвитку історії економічної думки, на базі чого узагальнено специфічні особливості процесу інвестування, визначено поняття арт-інвестування. Розроблено аналітико-прикладне забезпечення мінімізації ризиків інвестиційного портфелю арт-об'єктів за рівнем фінансової безпеки арт-інвестування на локальному арт-ринку та здійснено його апробацію на прикладі сформованого автором інвестиційного портфелю арт-об'єктів сучасних українських художників. Висновки. Розроблено аналітико-прикладне забезпечення мінімізації ризиків інвестиційного портфелю арт-об'єктів за рівнем фінансової безпеки арт-інвестування на локальному арт-ринку, що дозволяє на основі оцінки мультиплікатора оцінки інвестиційної привабливості арт-об'єктів встановити пріоритетність інвестування у арт-об'єкт у складі інвестиційного портфелю, визначити інвестиційний потенціал арт-об'єкта за компонентами фінансової безпеки арт-інвестування за параметрами внутрішнього середовища, здійснити позиціювання кожного арт-об'єкта на матриці з врахуванням емоційного ефекту від володіння арт-об'єктом для інвестора.

Ключові слова: інвестиційний портфель арт-об'єктів; арт-інвестування; фінансова безпека арт-інвестування; ризики арт-інвестування; інвестиційна привабливість арт-об'єктів; мультиплікатор інвестиційної привабливості арт-об'єкта; інвестиційний потенціал арт-об’єкта.

\section{ОПТИМИЗАЦИЯ РИСКОВ ИНВЕСТИЦИОННОГО ПОРТФЕЛЯ АРТ-ОБЪЕКТОВ ПО УРОВНЮ ФИНАНСОВОЙ БЕЗОПАСНОСТИ АРТ-ИНВЕСТИРОВАНИЯ НА ЛОКАЛЬНОМ АРТ-РЫНКЕ}

Статья посвящена исследованию теоретико-методических основ и разработке практических рекомендаций по оптимизации рисков инвестиционного портфеля арт-объектов по уровню финансовой безопасности арт-инвестирования на локальном рынке. Предметом исследования является совокупность теоретических, методических и практических аспектов по оптимизации рисков инвестиционного портфеля арт-объектов по уровню финансовой безопасности арт-инвестирования на локальном рынке. Целью статьи является разработка теоретико-методических положений и обоснование практических рекомендаций по оптимизации рисков инвестиционного портфеля арт-объектов по уровню финансовой безопасности артинвестирования на локальном рынке. Задачи работы: исследовать и систематизировать понятийно-категориальный аппарат обеспечения финансовой безопасности арт-инвестирования; разработать методический подход к оценке уровня инвестиционной привлекательности арт-объекта по уровню финансовой безопасности арт-инвестирования; предложить аналитико-прикладное обеспечение оптимизации рисков инвестиционного портфеля арт-объектов по уровню финансовой безопасности арт-инвестирования на локальном арт-рынка. В ходе исследования использованы методы: абстрактнологический анализ, теоретического обобщения, системного и статистического анализа, системный и статистический анализ, экономико-математические методы, графический метод. В работе определена сущность и генезис понятия инвестиций как экономической категории в контексте развития истории экономической мысли, на базе чего обобщены специфические особенности процесса инвестирования, определено понятие арт-инвестирования. Разработано аналитико-прикладное обеспечение минимизации рисков инвестиционного портфеля арт-объектов по уровню финансовой безопасности артинвестирования на локальном арт-рынка и осуществлено его апробацию на примере сформированного автором инвестиционного портфеля арт-объектов современных украинских художников. Выводы. Разработанное аналитикоприкладное обеспечение минимизации рисков инвестиционного портфеля арт-объектов по уровню финансовой безопасности арт-инвестирования на локальном арт-рынка, позволяет на основе оценки мультипликатора оценки инвестиционной привлекательности арт-объектов установить приоритетность инвестирования в арт-объект в составе инвестиционного портфеля, определить инвестиционный потенциал арт-объекта по компонентам финансовой безопасности артинвестирования по параметрам внутренней среды, осуществить позиционирование каждого арт-объекта на матрице с учетом эмоционального эффекта от владения арт-объектом для инвестора.

Ключевые слова: инвестиционный портфель арт-объектов; арт-инвестирование; финансовая безопасность артинвестирования; риски арт-инвестирования; инвестиционная привлекательность арт-объектов; мультипликатор инвестиционной привлекательности арт-объекта; инвестиционный потенциал арт-объекта.

\section{Бібліографічні описи / Bibliographic descriptions}

Момот Д. Т. Оптимізація ризиків інвестиційного портфелю арт-об'єктів за рівнем фінансової безпеки арт-інвестування на локальному арт-ринку. Сучасний стан наукових досліджень та технологій в промисловості. 2020. № 3 (13). С. 95-105. DOI: https://doi.org/10.30837/ITSSI.2020.13.095.

Momot, D. (2020), "Optimization of risks of the investment portfolio of art objects according to the level of financial security of art investing in the local art market", Innovative Technologies and Scientific Solutions for Industries, No. 3 (13), P. 95-105. DOI: https://doi.org/10.30837/ITSSI.2020.13.095. 